International Journal of Linguistics, Literature and Translation

ISSN: 2617-0299 (Online); ISSN: 2708-0099 (Print)

DOI: $10.32996 / \mathrm{ijllt}$

Journal Homepage: www.al-kindipublisher.com/index.php/ijllt

\title{
Multimodality and Translation: How Typography Affects the Quality of Translation
}

\author{
Bimo Putra Wicaksono ${ }^{1}$ (D) $ه$, M.R. Nababan ${ }^{2}$ (D) and Dyah Ayu Nila Khrisna ${ }^{3}$ (D) \\ ${ }^{1}$ Student of Linguistic Department in Sebelas Maret University, Indonesia \\ ${ }^{23}$ Lecturer of Linguistics Department in Sebelas Maret University, Indonesia \\ $\triangle$ Corresponding Author: Bimo Putra Wicaksono, E-mail: quiinscarecrow1313@gmail.com
}

\section{ARTICLE INFORMATION \\ Received: March 11, 2021 \\ Accepted: April 23, 2021 \\ Volume: 4 \\ Issue: 4 \\ DOI: 10.32996/ijllt.2021.4.4.25}

\section{KEYWORDS}

Emotional Expressions,

Multimodality, Translation

\section{ABSTRACT}

This research focuses on analyzing the typografi aspect of the translation of utterances that accompany the emotional expressions in the comic entitled "Avatar, The Legend of Aang; The Promise, The Search, and The Rift". The purposes of this research are; 1.) to find out the emotional expressions and the utterances that accompany the emotional expressions found in the comic entitled "Avatar, The Legend of Aang; The Promise, The Search, and The Rift", 2.) to find out the impact of the typography aspect found in the comic entitled "Avatar, The Legend of Aang; The Promise, The Search, and The Rift" on the quality of the translation. This research applied descriptive qualitative research. There are 273 data of utterances that accompany the emotional expressions found in the data source. The other data are translation quality assessments done by the raters. The data sources of this research are the English comic of "Avatar, The Legend of Aang; The Promise, The Search, and The Rift", its translation in Indonesian and also raters and respondents. All of the informants were chosen by the purposive sampling technique. The quality of utterances that accompany the emotional expressions in the comics entitled "Avatar, The Legend of Aang; The Promise, The Search, and The Rift" in terms of the accuracy of the messages as follows: the messages of 166 data are fully delivered and the messages of 107 data are not fully delivered.

\section{Introduction}

The comic is one of the works that is often found in most nations around the world. Comic involves a complex interaction between written language and the "visual language" of images, with one or the other guiding the meaning and/or narrative structure, so that comics can be called unique works as places of learning (Cohn, 2016). Visual and verbal aspects in comics can help each other strengthen the story's background.

Eisner (1985) said that in a comic, verbal and visual aspect could be used to develop a depiction that expresses moods through the type of fonts and textures. In addition, the use of both aspects in comics can be used to show the emotional expression a character puts out. These emotional expressions can be in the form of anger, sadness, joy, etc.

In his research, Ekman (1977) divided human emotional expression into 6 basic emotions; fear, surprise, joy, anger, sadness and disgust. Every emotional emotion has a characteristic that can be described and applied in a comic. These characteristics can be in the form of portrayal in the verbal and visual aspects.

The depiction of emotional expressions in the comics makes the story and the characters feel more alive. The verbal aspect refers to the speech in the balloon dialogue when a character speaks and there are onomatopoeic words that support it. Meanwhile, visual aspect is about facial expressions, the image around the character when the character says something, colors, and page layouts (Yablonsky, 2016 ).

\section{K C AL-KINDI CENTER $\mathbf{R}$ D FOR RESEARCH AND DEVELOPMENT} Your gateway to world-class research

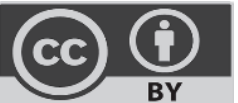

Published by Al-Kindi Center for Research and Development, London, United Kingdom. Copyright (c) the author(s). This open access article is distributed under a Creative Commons Attribution (CC-BY) 4.0 license 
Each country has its own unique comics with different languages and images. In these comics there are differences in language and culture. This difference lies in the two dominant aspects of a comic: the visual and verbal aspects. Connor (2017) argues that literacy is a combination of a person's various abilities and applying these aspects in society when a person uses one or more modes to create a message.

Mode is a system of a combination of verbal and visual created in various cultures to convey messages (Serafini, 2014). Later, if one country wants to adopt comics from another country, language and cultural differences will be essential in expressing messages in the visual and verbal aspects. In some cases, another aspect is called the typographic aspect. Kaindl (1999) states that three aspects must be considered in a comic; visual, verbal, and typography.

The three aspects proposed by Kaindl are also found in the work entitled "Avatar, The Legend of Aang; The Promise, The Search, and The Rift". The works are famous works that have been recognized in various countries and won various awards. One of the teams that was obtained was in 2013. TV Guide included Avatar among the 60 greatest cartoons of the all-time list. In 2018, Vanity Fair ranked the series as the 11th-best animated TV show. Avatar was ranked the 36th-best animated series on IndieWire's 2018 list of the "50 Best Animated Series Of All Time". That makes the other nations, including Indonesia, interested in broadcasting the series.

In order to be published in Indonesia and to be accepted by the readers, "Avatar, The Legend of Aang; The Promise, The Search, and The Rift", which was originally written in English, must be translated into Indonesian. In translating the works, or translating dialogue in a comic for more precise, the factor that the translator must pay attention to is not only how the messages in text in dialogue balloons are delivered, but also how the visual aspects in the comic are showed, and the same writing between the source language and the target language. The harmony of these three aspects will create nuances in the source language that the writer wants to convey in the source language delivered equally in the target language.

The aim of this research is to describe how the aspect of typography affects the quality of the translation. This research was conducted using the descriptive qualitative method dan applied a multimodality approach. This research is only limited in describing the typography aspect in the emotional expressions in the comic series "Avatar, The Legend of Aang". To find expressions that contain emotional expressions, the researcher used the multimodality approach. After the type of emotional expressions and the multimodality aspects were determined, the conclusion will be made whether the typography aspect affects the comic translation quality.

\section{Methodology}

This study used the descriptive qualitative method. Thus, this research will focus more on a translation result, not on the translation process (Nababan, 2007). This research will be conducted to describe how an aspect of multimodality, aspect of typography, affects the translation of the translation. This research will use a multimodality approach to determine the emotional expressions of the characters in the comics. Later, the text that is in the dialogue balloon accompanying the emotional expressions will be taken as data.

The location in this study includes 3 main elements, namely setting, participant, and event (Spradley in Santosa, 2017). Referring to this statement, the research took the setting, participant, and event from 3 additional comics from the series "Avatar, The Legend of Aang; The Promise, The Search, and The Rift". In addition, this research also took the data sources from documents (comics in English and Indonesian) and informants, raters who helped determine the translation quality.

This research took the data from the three additional comics of "Avatar, The Legend of Aang; The Promise, The Search, and The Rift ". The data are in the form of interjections, words, phrases, and sentences that accompany the comic's emotional expressions. The data were determined by the writer with the help of the raters in a Focus Group Discussion (FGD). In the FGD, the content analysis was used to sort the dialogues that can be included as data and the dialogues that can not be included. The determination of the data is based on six basic emotional expressions proposed by Ekman (1977). This study also uses other theories as a basis for conducting research. Another theory used is the multimodality theory in comics proposed by Kaindl (1999). The theory was used to determine the multimodality aspects in the data.

\section{Results and Discussions}

The result shows that there are six emotional expressions found in the comic entitled "Avatar, The Legend of Aang; The Promise, The Search, and The Rift "; surprise, pleasure, anger, sadness, fear, and disgust. Each of the emotional expressions has a different number of data. Emotional expressions of surprise appeared the most, with 86 data of 273 data. Meanwhile, the expression which has the second occurrence rate is happy, with 71 of 273 data. Then, emotional expression of anger with 61 data, the expression of sad with 23 data, emotional expression of fear with 22 data, and the last is the emotional expression of disgust with 12 data of 273 . 
This research also found the application of the multimodality aspects that are used in the comic. The multimodality aspect mentioned above is the visual aspect, the verbal aspect, and the typography aspect. In reality, the comic uses a combination of two aspects and three multimodal aspects and no data uses only one multimodal aspect. The use of two multimodality aspects is a combination of visual aspects and verbal aspects, while the use of three multimodality aspects is a combination of visual aspects, verbal aspects and typographic aspects. The results of this study indicate that the use of three multimodal aspects dominates the comic. 142 data use two multimodality aspects in the comic "Avatar, The Legend of Aang; The Promise, The Search, and The Rift" and there are 131 data that use three multimodality aspects in the comic in the source language. After the data were translated into the target language, the number of these aspects changed. After the data were translated into the target language, the number of these aspects changed. After being translated, two multimodality aspects increased to 218 data. Meanwhile, three multimodality aspects in the comic were reduced to only 45 data. The changes are caused by the existence of data in the source language with three multimodality aspects that are not translated into the target text with three multimodality aspects.

The findings of this study indicate that there are changes in the use of multimodality aspects in the comic "Avatar, The Legend of Aang; The Promise, The Search, and The Rift" after experiencing the translation process. In the comic, the use of the third aspect, namely the typography aspect, is indicated by the presence of lingual units with a bold and italic font together. The use of typography aspect of the use of different fonts has the meaning to show that something is emphasized in a text or shows an increasing intonation of a character's speech. If the lingual unit with this typographic aspect is not translated in the same way, the message contained in the text is feared to be lost. The following is an example of the use of multimodality aspects in the comic "Avatar, The Legend of Aang; The Promise, The Search, and The Rift":

\subsection{Exampels of Three Aspects of Multimodality in Comic}

a) Messages Completely Delivered

\section{Context}

Toph's appreantices tell her that they left their house because they were kicked out by someone who claimed that Toph's current house belonged to a state college of fire. Toph was angry because she felt that she already owned the whole house as her place to practice metalbending.

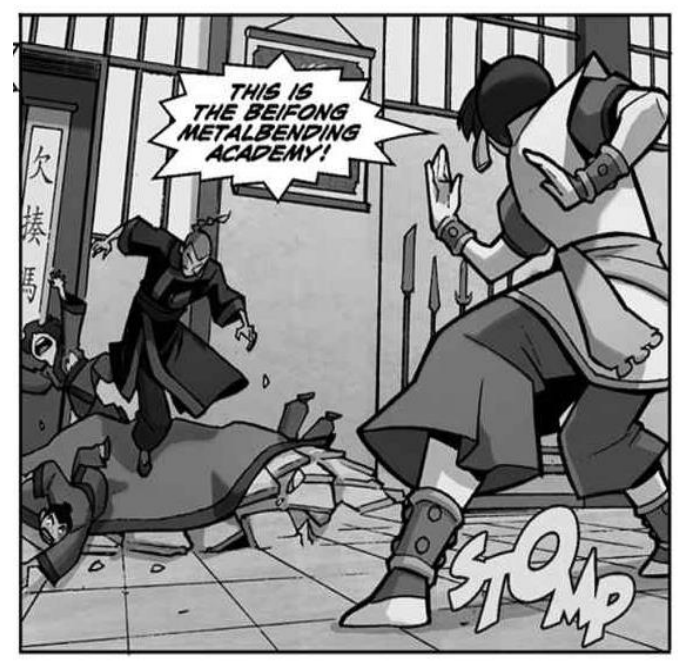

Teks BSu:

"This is the Beifong Metalbending Academy!"

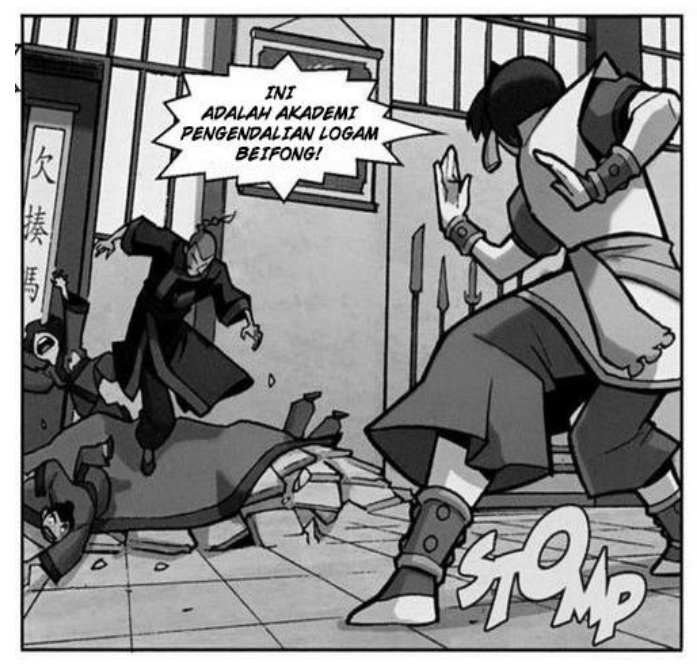

Teks BSa:

"Ini adalah akademi pengendalian logam Beifong!"

The angry Toph started saying "This is the Beifong Metalbending Academy!". The sentence was translated into "Ini adalah akademi pengendalian logam Beifong!" in its translation in the target language. The example above succeeds in conveying the message from the source language to the target language. One section in the source language expression uses the bold font, and in the target language, that part has also been shown. This is considered all the messages are delivered completely because the messages conveyed in the source language are not reduced or missed. 
b) Messages Not Delivered Completely

\section{Context}

Outside the Fire Lord's residence, demonstrators grow impatient and question what Aang is doing inside with the Fire Lord. They grow impatient and ask to enter the Fire Lord's residence. However, Sokka, who is there trying to calm the demonstrators, is ignored. So, Toph, who does not like her friend being ignored, begins to calm the demonstrators in a harsh way.

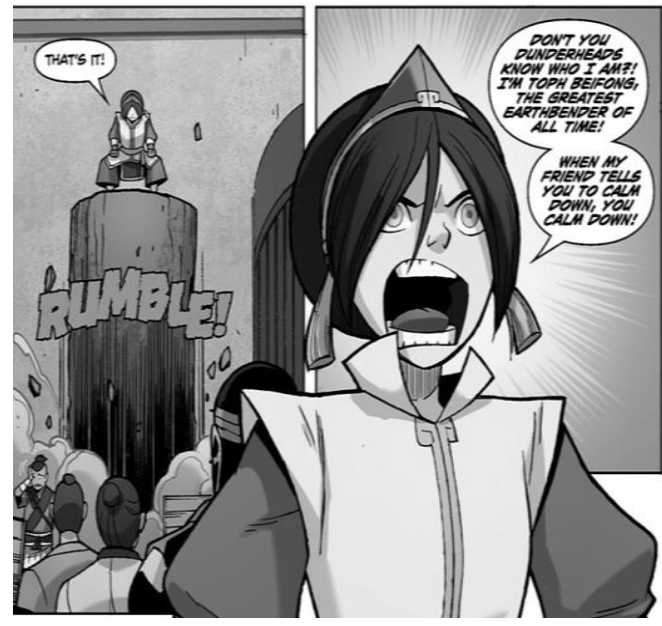

Teks BSu:

"Don't you dundernheads know who I am?! I'm Toph Beifong, the greatest earthbender of all time! When my friend tells you to calm down, you calm down!"

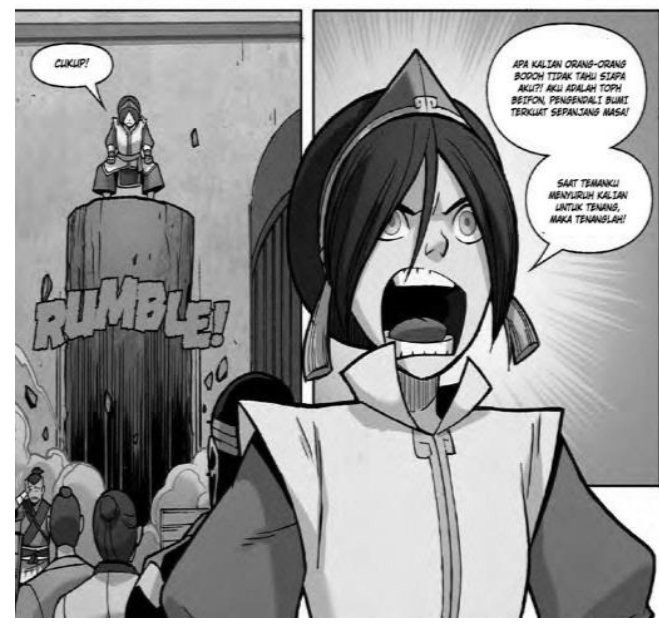

Teks BSa:

"Apa kalian orang-orang bodoh tidak tahu siapa aku?! Aku adalah Toph Beifon, pengendali bumi terkuat sepanjang masa! Saat temanku menyuruh kalian untuk tenang, maka tenanglah!"

In the example above, Toph is seen talking in a loud voice to the people demonstrating in front of Fire Lord's residence. At that time, there is a large-scale demonstration that the citizens of the Earth kingdom hold in a Fire Nation city. Initially, Sokka asks the demonstrators to calm down before a decision is made between the two parties, but the demonstrators do not heed Sokka's request. It was then that the angry Toph started to say, "Don't you dundernheads know who I am?! I'm Toph Beifong, the greatest earthbender of all time! When my friend tells you to calm down, you calm down!". In its translation in the target language the expression was translated into "Apa kalian orang-orang bodoh tidak tahu siapa aku?! Aku adalah Toph Beifong, pengendali bumi terkuat sepanjang masa! Saat temanku menyuruh kalian untuk tenang, maka tenanglah!" The example above has succeeded in conveying the message as a whole from the source language to the target language. However, one part of the multimodality aspect of the source language does not exist in the target language; the typography aspect. One part of the source language expression uses bold font and italicized, but that aspect is not shown in the target language. In this regard, the translation does not convey the message as a whole because part of the messages conveyed in the source language is not delivered or missed in the target language. In the source language, using bold and italic fonts is used to display the speaker's high pitch, but in the target language, this aspect is not displayed so that the speaker appears to be speaking in a normal tone. Translations in the target language can be more complete when it was translated into "Apa kalian orang-orang bodoh tidak tahu siapa aku?! Aku adalah Toph Beifong, pengendali bumi terkuat sepanjang masa! Saat temanku menyuruh kalian untuk tenang, maka tenanglah!". That way, the messages in the expression are completely delivered, both in the message inside the text and its multimodality aspects.

\section{Conclusion}

This research will be conducted to find out the comic's emotional expressions and describe how multimodality, an aspect of typography, affects translation. Each emotional expression in the comic Avatar uses multimodality aspects proposed by Kaindl (1999). There are texts with two aspects of multimodality, and there are texts that use three aspects of multimodality. The translator is asked to convey the message contained in the text. However, in contrast to translating text that only has a verbal aspect in it, translators need to pay attention to other aspects such as typographic aspects when translating. This is because messages in comics are limited to the verbal aspect in the form of a dialogue between characters and on two other aspects; visuals and typography. In research conducted by Heath (2018), it shows that there are different functions in using words with capital letters and words with ordinary letters. The use of capital letters in a text is often used as a sign of a different focus and 
sometimes it has higher intonation than written in regular or common letters. The use of bold and italic typographic aspects in "Avatar, The Legend of Aang; The Promise, The Search, and The Rift" is considered a substitute for the capital letters because all the dialouges inside the comic using capitalized letters. If a text in a datum has different typographic aspects; having bold and italic fonts, translated without the same aspects in the target language, means that the message in the datum is not completely delivered to the target language reader. In this case, the role of the translator is needed to convey the message in the text as a whole without the message being shifted or reduced. This research is only limited in describing emotional expressions in a comic and how an aspect of multimodality affects the quality of the translation. The writer of this research hopes that more research examines the relationship between aspects of multimodality and translation, not only using one aspect but also covering two other aspects.

Funding: This research received no external funding

Acknowledgments: This article is a part of my thesis research. Therefore, I would like to say thank you to my supervisors Prof. Drs. M.R. Nababan, M.Ed., M.A., Ph.D. and Dr. Dyah Ayu Nila Khrisna, S.S., M.Hum. for their continuous support, advice and suggestions.

Conflicts of Interest: The authors declare no conflict of interest

\section{References}

[1] Cohn, N. (2016). From visual narrative grammar to filmic narrative grammar: The narrative structure of static and moving images. In Wildfeuer, Janina \& John A. Bateman (eds.). Film text analysis: New perspectives on the analysis of filmic meaning. (pp. 94-117). Routledge.

[2] Connors, S. P. (2017). Designing meaning: A multimodal perspective on comics reading. In C. Hill (Ed.), Teaching comics through multiple lenses: Critical perspectives. New York, NY: Routledge..

[3] Eisner, W. (1985). Comics and sequential art. New York/London: W. W. Norton \& Company

[4] Ekman, P. \& Friesen, W. V. (1977). Manual for the facial action coding system, Palo Alto: Consulting Psychologists Press

[5] Heath, M. (2018). Orthography in social media: Pragmatic and prosodic interpretations of caps lock. Proceedings of the Linguistic Society of America. 3. 55. 10.3765/plsa.v3i1.4350.

[6] Kaindl, K. (1999). Thump, Whizz, Poom: A Framework for the Study of Comics under Translation. Target-international Journal of Translation Studies, 11, 263-288.

[7] Nababan, M. R. (2007). Aspek Genetik, Objektif, dan Afektif dalam Penelitian Penerjemahan. Linguistika, 14(26), 15-23.

[8] Santosa, R. (2012). Metode penelitian kualitatif. Surakarta: Universitas Sebelas Maret.

[9] Serafini, F., \& Gee, J. P. (2014). Reading the visual: an introduction to teaching multimodal literacy. New York: Teachers College Press.

[10] Yablonsky, M. (2016). Text and image in translation. CLEaR. 3. 10.1515/clear-2016-0013.

[11] Yang, L. (2012). Avatar: The Last Airbender: The Promise. Oregon, Dark Horse Comic.

[12] Yang, L. (2013). Avatar: The Last Airbender: The Search. Oregon, Dark Horse Comic.

[13] Yang, L.(2014). Avatar: The Last Airbender: The Search. Oregon, Dark Horse Comic 